\title{
THE DOLICHOPODID GENUS NEMATOPROCTUS LOEW IN NORTH AMERICA
}

\author{
By M. C. VAN DUZeE \\ Buffalo, N. Y.
}

This genus was established in 1857, Neue Beitr., Vol. v, p. 40, for two species. The type designation by $D$. W. Coquillett, Chrysotus distendens Meig. as Porphyrops annulatus Macq., the first species mentioned.

Including the three species described here there are thirteen species known, three from Europe, two from Java, one from Africa and six from North America.

The species of this genus differ from those of Argyra by having the first antennal joint bare above, third short, rather rounded, with a nearly basal arista.

Dr. T. Becker places Nematoproctus, Argyra and its subgenus Leucostola in the Diaphorinæ. Dr. J. M. Aldrich includes them in the Rhaphiinæ, to which they seem to me to be much more closely related; we have species of Argyra which are separated from the Porphyrops group of Rhaphium by having from one to three small hairs on upper surface of first antennal joint and the arista not quite apical. Nematoproctus is separated from the subgenus Leucostola by the small third antennal joint with its dorsal arista and the longer hypopygial appendages of the male.

\section{Key to the species of North American Nematoproctus}

1. Orbital cilia and the beard yellow; tarsi of male plain (New Jersey) .......................venustus Melander Orbital cilia and beard snow white .......................... 2

2. Feet ornamented ................................................... 3

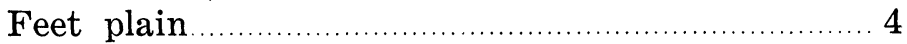


3. Middle tarsi with last two joints a little flattened and widened (Va., N. Y., Ohio)

\section{terminalis Van Duzee}

First joint of fore tarsi fringed with long black hairs on apical half, second joint on whole length (Pennsylvania) ......................................junctus Van Duzee

4. Posterior edge of pleuræ and first three abdominal segments yellow (Connecticut)

flavicoxa new species

Pleuræ wholly black; second and third abdominal segments yellow, at least on the sides.

5. First and second abdominal segments wholly yellow, except very narrow anterior and posterior margins; hind femora almost wholly yellow (Connecticut) varicoxa new species

Second and third abdominal segments with yellow on the sides; hind femora black above (Pennsylvania) ...................................metallicus new species

\section{Nematoproctus flavicoxa new species}

Male: Length $5 \mathrm{~mm}$.; of wing $4.5 \mathrm{~mm}$. Face nearly as wide as the front, silvery white, its sides parallel; palpi longer than width of face, scarcely half as wide as long, yellow; front green, white pollinose; antennæ black, first joint mostly yellowish, bare above, third joint small, about as long as wide, somewhat conical, arista inserted near the base; occiput green with bronze reflections above the neck; orbital cilia white, a few of the upper cilia black.

Thorax blue-green, dorsum very shining, front slope grayish white pollinose, reddish coppery spots extend along the sides from the suture over the roots of the wing; pleuræ white pollinose, posterior edge yellow; first three abdominal segments yellow, hind margins of these segments narrowly black, the yellow portion shows very slight green reflections; fourth and fifth segments green with 
coppery reflections at base, sixth violet; venter yellow; dorsum of abdomen and sides beyond second segment with black hair; sides of second with long yellow hair; hypopygium black with numerous bristly hairs on posterior surface, its outer lamellæ black, as long as height of hypopygium, fringed with stiff black hairs on outer edge; no inner appendages visible, except a hair-like one.

Coxæ yellow, anterior pair with rather long, abundant, pale yellow hair and three long and three short black bristles near tip; middle coxæ blackened on outer surface of basal half, their hair pale yellow; posterior ones with one erect bristle on outer surface; all femora and fore and middle tibiæ wholly yellow; basal two thirds of hind tibiæ yellow, spical third black; fore and middle femora with rather short, yellowish hairs below; fore and middle tarsi yellow, becoming blackish towards tip; hind tarsi wholly black; first joint of fore tarsi with a row of longer hairs below, which are shortest at tip and extend along second joint; joints of fore tarsi as 45-16-11-9-9 ; of middle ones as 57-24-20-11-9; joints of posterior pair as 41-39-26-17-11. Calypters and their cilia whitish; halteres pale yellow.

Wings nearly uniformly tinged with brownish gray; third vein bent backward towards their tips; last section of fourth vein slightly and gradually bent forward from near its middle, then backward so as to be parallel with third at tip, ending in apex of wing; last section of fifth vein straight, it is as 57 , cross-vein as 22 ; sixth vein a little sinuous; anal angle of wing prominent.

Described from one male, taken by C. H. Curran, June 22, 1929, at Avon Old Farms, Avon, Connecticut.

\section{Nematoproctus metallicus new species}

Male: Length $3.5 \mathrm{~mm}$.; of wing the same. Face narrow, not half as wide as front, silvery white, its sides parallel; palpi narrow, longer than width of face, yellow, silvery white pollinose; front blue-green, white pollinose; antennæ black, first joint wholly yellowish, bare above, rather long; third joint moderately large, conical, about as long as wide, arista inserted near its base; occiput black, green just back 
of the vertex, white pollinose; orbital cilia white, only a few of the very small upper cilia black.

Thorax green, dorsum shining, anterior edge dulled with gray pollen; posterior edge of pleuræ black, but seen from behind the space above and between the hind coxæ is yellow; dorsum of abdomen green, three first segments with coppery reflections, fourth and fifth more bluish, sixth wholly blue; sides of second and third segments with large yellow spots; venter of first four segments yellow with a few small yellow hairs, hairs on dorsum black; hypopygium black with only a few short black hairs on posterior surface, outer lamellæ black, narrow, as long as height of hypopygium, fringed with stiff black hairs and a few white ones, inner appendages short, stout, with a few minute hairs.

All coxæ, femora and tibiæ yellow; fore coxæ with a few yellow hairs and two black bristles; tips of hind femora black above; most of apical half of hind tibiæ and whole of their tarsi black; fore and middle femora with short yellow hairs below; fore and middle tarsi black from tip of first joint; first joint of fore tarsi with a row of hairs of nearly equal length below, which are about as long as diameter of joint and continued the whole length of second joint, all joints of fore tarsi with long hairs at tip, above; joints of fore tarsi as 33-14-9-7-7; of middle ones as 40-18-14-7-6; first three joints of hind tarsi as 30-31-18. Calypters and their cilia whitish; halteres pale yellow.

Wings tinged with brownish gray; third vein bent back at tip; last section of fourth vein a little arched, parallel with third at tip, ending just back of apex of wing; last section of fifth vein nearly twice as long as cross-vein; sixth vein a little sinuous; anal angle of wing prominent.

Described from one male, taken by the author, June 4, 1925, in the bed of the old canal, near Amnity Hall, Benvenue, Pennsylvania. Type in the author's collection.

Nematoproctus varicoxa new species

Male: Length $5 \mathrm{~mm}$; of wing $4 \mathrm{~mm}$. Face rather narrow, a little more than half as wide as the front, silvery white, its sides parallel; palpi yellow, about as long as 
width of face, with many black hairs, which are nearly as long as the palpi ; front blue-green, with white pollen; antennæ black, first joint bare above, a little yellowish below, third small, somewhat conical, as long as wide, arista basal; occiput green, white pollinose; orbital cilia and the beard white, a few of the minute upper cilia black.

Thorax blue-green, dorsum bright, shining with a little white pollen on the front slope; reddish coppery spots on the sides extend from the suture over the root of the wings; pleuræ more black, especially the posterior edge, a little white pruinose; first abdominal segment coppery and green, with long black bristles above; second and third segments yellow, second narrowly black at base and very narrowly on hind margin; third segment with a narrow, sharply defined, white pollinose band at base, followed by a black band of equal width, posterior margin very narrowly black; fourth purplish black on basal half, more green on apical half, fifth colored as the fourth, only more blue posteriorly, sixth segment small, violet; hairs on dorsum of abdomen black, on lower edge of sides of three basal segments long and yellow, above these are a few long black hairs; venter with many long yellow hairs; hypopygium black, posterior surface with about twelve bristles; outer lamellæ black, narrow, about as long as height of hypopygium, fringed on one side with stiff black hairs; two pair of inner appendages, first black, wide at base, tip somewhat knob-like with several minute spines, the other yellowish, hair-like, about half as long.

Fore coxæ wholly pale yellow, with rather long yellow hair, four large black bristles and one small one; middle and hind coxæ black with yellow tips; all femora and tibiæ yellow, hind femora a very little darkened at tip, hind tibiæ blackened from near their middle, extreme tip of middle tibiæ sharply black; fore and middle femora with long yellow hairs on lower surface; fore tibiæ with a row of rather long black hairs on lower posterior edge and a row of about six bristles on upper posterior edge of basal half, which are longer than diameter of tibia; tarsi plain, anterior ones yellow with last three joints blackish, first joint with a row of stiff black hairs below, these are as long as 
width of joint at base, becoming shorter towards the tip, they are continued on the following joints, long on second, shorter on third and quite short on two last joints ; middle tarsi yellowish with tips of first two joints and whole of last three brown; hind tarsi wholly black; joints of fore tarsi as 45-19-12-9-9; of middle ones as 57-20-20-10-10; joints of posterior pair as 37-41-27-16-9. Calypters and their cilia whitish; halteres yellow.

Wings slightly tinged with brownish gray; third vein bent backward at tip; fourth vein scarcely parallel with third except at tip, not but little bent, ending just back of apex of wing; last section of fifth vein as 51, cross-vein as 30 ; sixth vein sinuous; anal angle of wing prominent.

Described from one male, taken by C. H. Curran, June 25, 1929, at Avon Old Farms, Avon, Connecticut. Type in the American Museum.

The three forms described in this paper are very much alike in the form of fore tarsi, color of wings and form of the long outer hypopygial appendages. Metallicus has the abdomen wholly metallic above, tips of hind femora conspicuously black above at tip and third antennal joint a little larger; flavicoxa differs from both the others in having the tibiæ and femora wholly yellow, and the posterior margin of pleuræ yellow, it differs from varicoxa in having all coxæ yellow, middle tibiæ wholly yellow. They all differ from each other in the form of the palpi, bristles on posterior surface of hypopygium and the inner hypopygial appendages. 

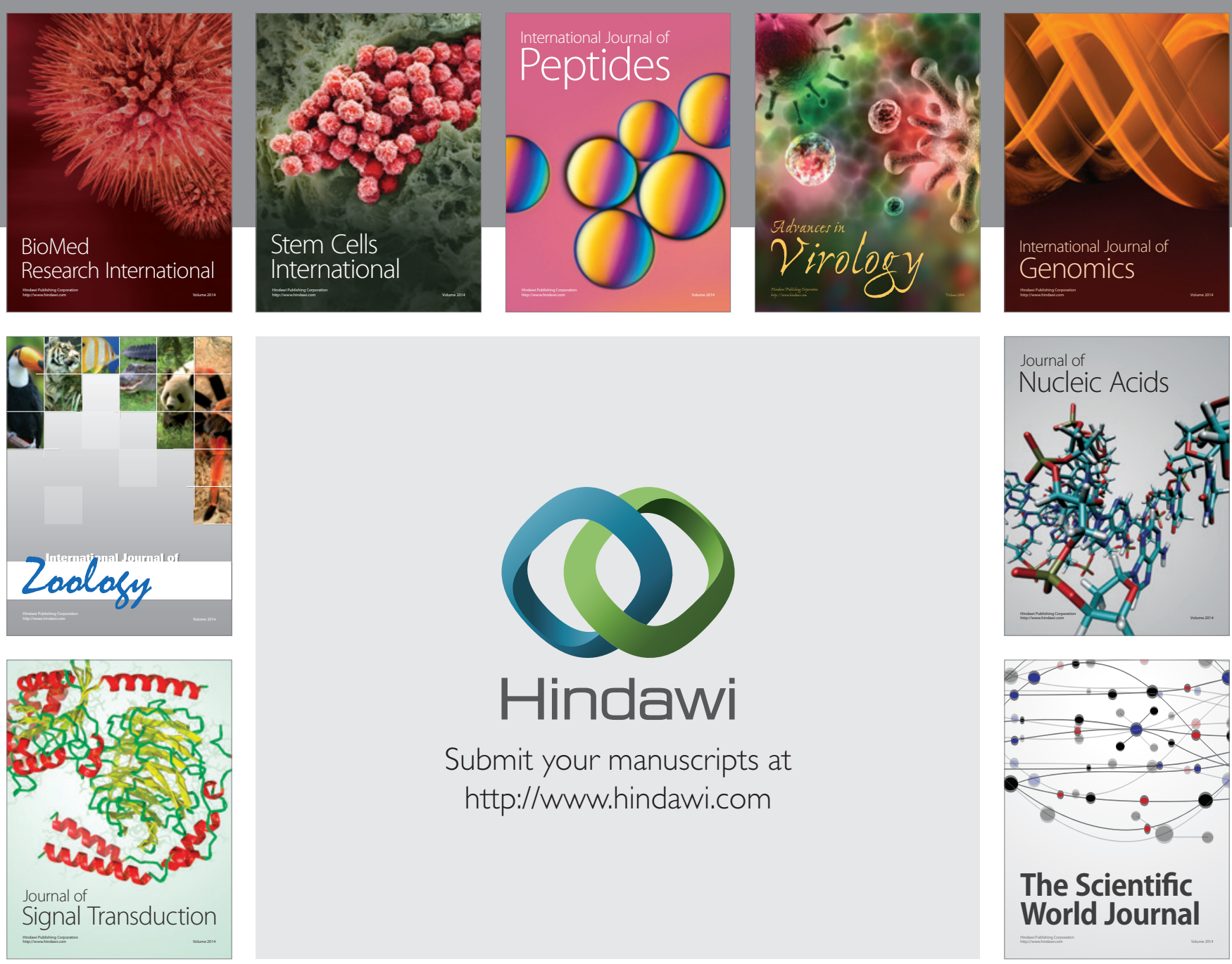

Submit your manuscripts at

http://www.hindawi.com
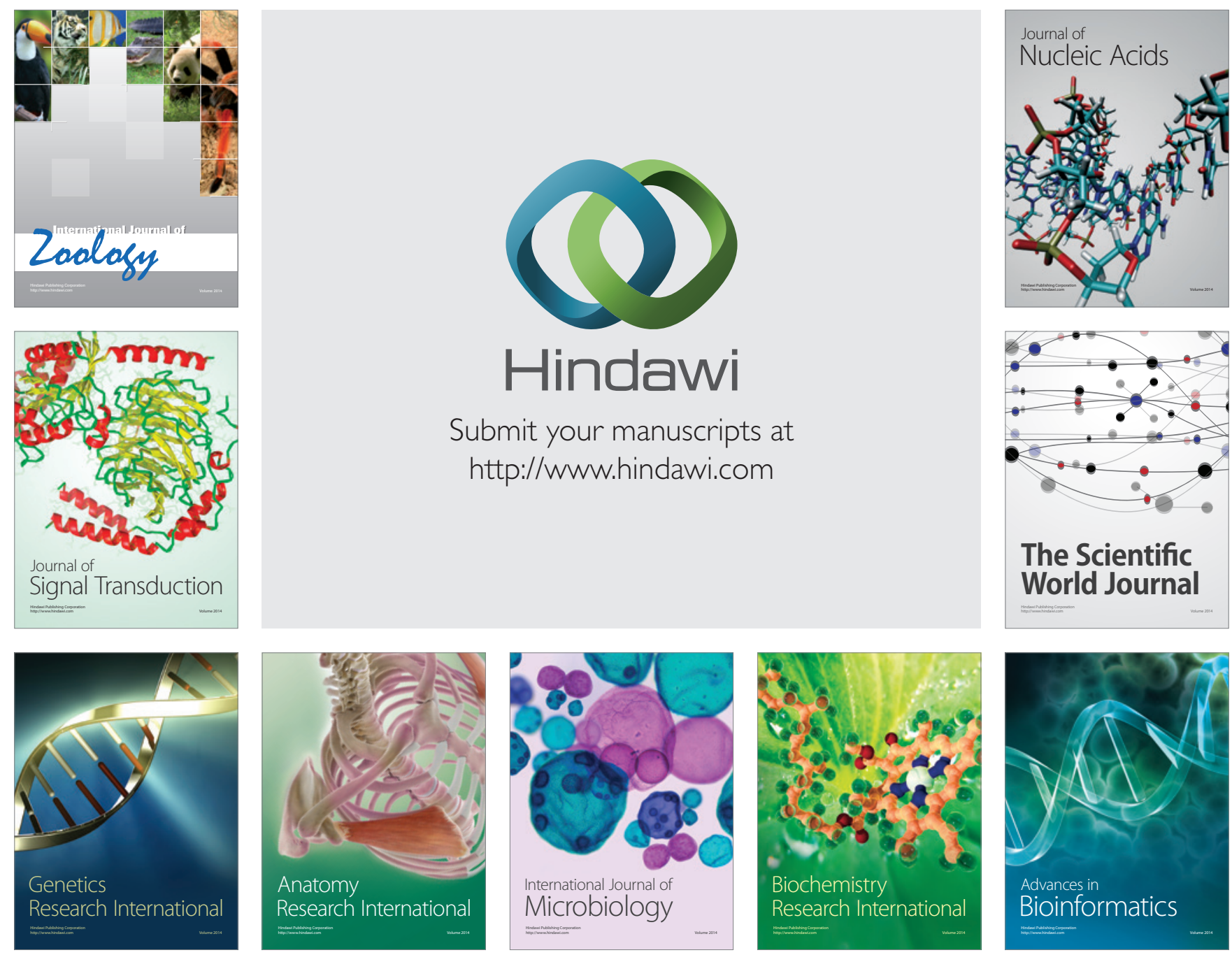

The Scientific World Journal
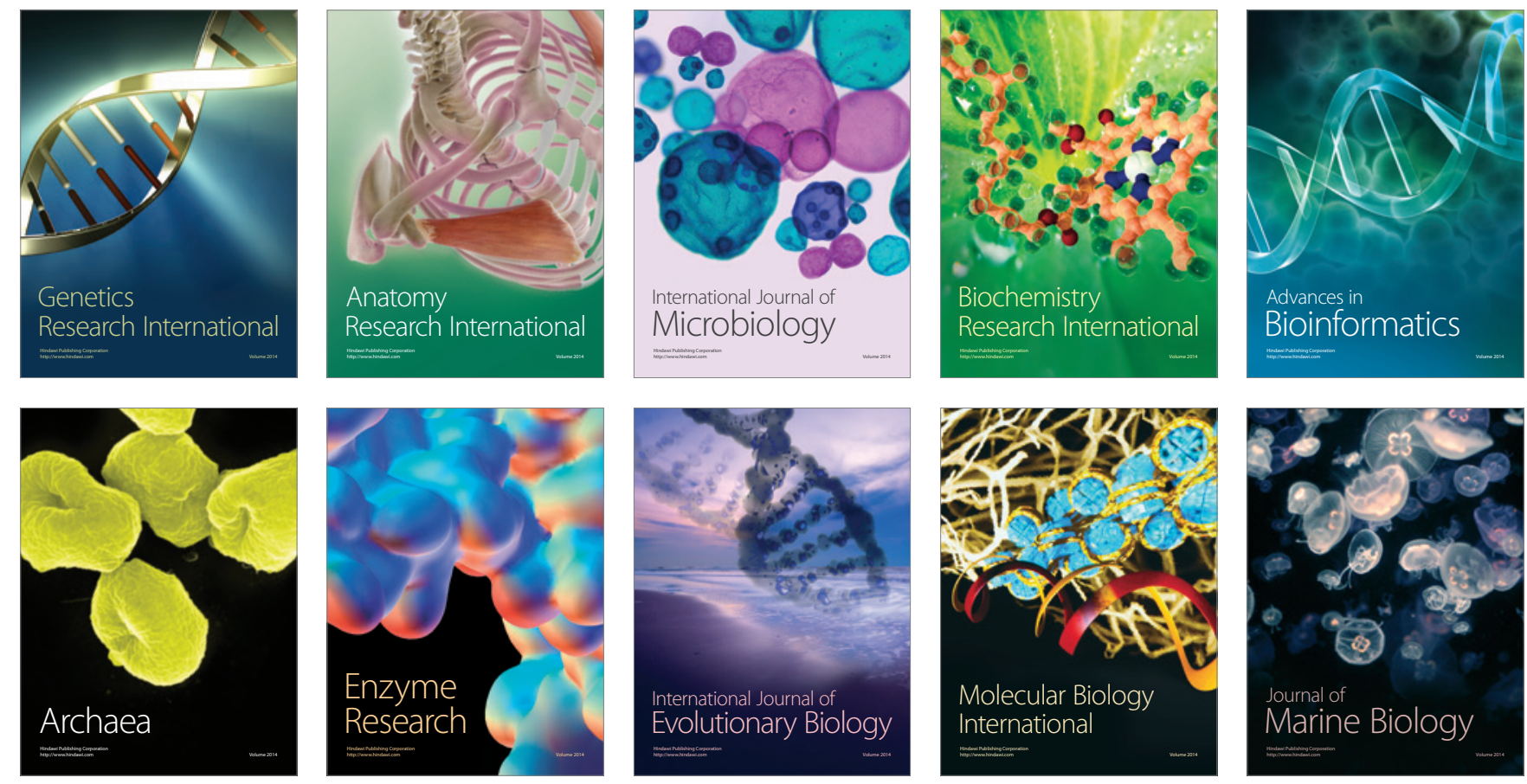